\title{
Evaluation of Chlorella (Chlorophyta) as Source of Fermentable Sugars via Cell Wall Enzymatic Hydrolysis
}

\author{
Marcoaurélio Almenara Rodrigues ${ }^{1}$ and Elba Pinto da Silva Bon ${ }^{2}$ \\ ${ }^{1}$ Laboratory of Studies Applicable to Photosynthesis (LEAF), Biochemistry Department, Center of Technology, \\ Chemistry Institute, Federal University of Rio de Janeiro (UFRJ), Bloco A, Avenida Athos da Silveira Ramos 149, \\ Ilha do Fundão, 21 941-909 Rio de Janeiro, RJ, Brazil \\ ${ }^{2}$ Enzyme Technology Laboratory (ENZITEC), Biochemistry Department, Center of Technology, \\ Chemistry Institute, Federal University of Rio de Janeiro (UFRJ), Bloco A, Avenida Athos da Silveira Ramos 149, \\ Ilha do Fundão, 21 941-909 Rio de Janeiro, RJ, Brazil
}

Correspondence should be addressed to Marcoaurélio Almenara Rodrigues, almenara@iq.ufrj.br

Received 23 December 2010; Accepted 28 February 2011

Academic Editor: Mohamed Kheireddine Aroua

Copyright ( $) 2011$ M. A. Rodrigues and E. P. D. S. Bon. This is an open access article distributed under the Creative Commons Attribution License, which permits unrestricted use, distribution, and reproduction in any medium, provided the original work is properly cited.

The cell wall of Chlorella is composed of up to $80 \%$ carbohydrates including cellulose. In this study, Chlorella homosphaera and Chlorella zofingiensis were evaluated as source of fermentable sugars via their cell wall enzymatic degradation. The algae were cultivated in inorganic medium, collected at the stationary growth phase and centrifuged. The cell pellet was suspended in citrate buffer, $\mathrm{pH} 4.8$ and subjected to 24 hours hydrolysis at $50^{\circ} \mathrm{C}$ using a cellulases, xylanases, and amylases blend. The measurement of glucose and reducing sugars concentration in the reaction mixture supernatant, on a dry biomass base, showed hydrolysis yields of $2.9 \%$ and $5.03 \%$ glucose and $4.8 \%$ and $8.6 \%$ reducing sugars, for C. homosphaera and C. zofingiensis, respectively. However if cells were washed with chilled ethanol, cold dried, and grounded the biomass hydrolysis yields increased to $23.3 \%$ and $18.4 \%$ glucose and $24.5 \%$ and $19.3 \%$ reducing sugars for C. homosphaera and C. zofingiensis, respectively.

\section{Introduction}

The commitment of several nations to reduce the carbon dioxide emissions has given a great impulse to the development of alternative energy sources not based on fossil sources but rather on renewable resources. Plants and algae are good candidates, as alternative energy sources, as they obtain their energy from the sunlight and build up their biomass by removing carbon dioxide from atmosphere through photosynthesis. In this way, any time a fuel originated from plants or algae is burnt, the carbon dioxide emitted is the very same that was previously removed by those organisms. However, differently from plants, algae cultivation does not compete for land crop occupation. Microalgae are particularly attractive as they are photoautotrophic organisms that grow in simple inorganic medium and contrary to higher plants, each cell is photosynthetically competent so that the amount of carbon dioxide fixed is much higher in a biomass base [1]. Moreover, its cell wall structure does not present lignin, which can be advantageous to the enzymatic hydrolysis of its polysaccharide components [2].

Considering the structure of the cell wall, some Chlorella species possess an outer cell wall layer and an inner cell wall layer, while other species present only the inner cell wall layer [3]. The outer cell wall layer consists of two types of ultrastructure. In the first one it is observed a trilaminar structure and the presence of algaenan which is a highly resistant, nonhydrolyzable aliphatic biopolymer composed of long-chain even-carbon-numbered $\omega 9$-unsaturated $\omega$ hydroxy fatty acid monomers varying in chain length from 30 to 34 carbon atoms. These monomers are intermolecularly ester linked to form linear chains in which the unsaturations act as the starting position of ether cross-linking [4-6]. The second type of outer cell wall layer shows a homogeneous ultrastructure and as such, the trilaminar layer and algaenan are absent $[6,7]$. C. zofingiensis and C. homosphaera are 
amongst those species that possess trilaminar layer and possibly algaenan in their cell wall $[6,8]$. The inner cell wall layer shows high cellulose content $[9,10]$ and is prone to chemical and enzymatic degradation. It is composed of a matrix and a rigid fibrillar structure, which was called by Takeda and Hirokawa "rigid cell wall" [11]. The matrix is soluble in alkalis and trifluoroacetic acid while the so-called "rigid cell wall" is hydrolyzed upon $\mathrm{HCl}$ or $\mathrm{H}_{2} \mathrm{SO}_{4}$ treatment.

The sugar composition of the algae cell wall has been studied. The cell wall of microalgae belonging to the Chlorophyte division may reach up to $80 \%$ in carbohydrate content, as is the case for Chlorella fusca [12]. The composition and the cell wall structure is species dependent and may be used as taxonomical markers [13-15]. As such, the genus Chlorella comprises of species in which the "rigid cell wall" is composed of polysaccharides formed mainly by glucose and mannose and those in which this structure is composed of polysaccharides formed mainly by glucosamine. The sugar composition of the cell wall matrix of the first group is dominated by mannose and fucose whereas in the second group galactose, fucose, and sometimes xylose are the main sugars found $[11,13,14]$. The cell wall sugar composition of C. zofingiensis is $70 \%$ glucose and $30 \%$ mannose in its "rigid cell wall" and 65\% mannose, 30\% glucose, plus minor amounts of rhamnose and galactose in its matrix cell wall [14]. Concerning cell wall sugar composition of $C$. homosphaera, whose synonymy with Chlorella minutissima has been recently established [8], it presents $85 \%$ glucose $15 \%$ mannose in its "rigid cell wall" and 70\% mannose, $20 \%$ glucose, and $10 \%$ galactose in its matrix cell wall [14].

Accordingly, Chlorella cell wall is a good source of fermentable sugars, mostly cellulose derived, not to mention its starch content [16], provided these polysaccharides are properly hydrolyzed.

This work aims to evaluate the use of Chlorella, a green microalgae, as source of fermentable sugars for second generation ethanol production, via the enzymatic hydrolysis of its cell wall polysaccharides and intracellular starch content.

\section{Materials and Methods}

2.1. Cells and Growth. Cells of Chlorella zofingiensis and C. homosphaera were maintained in inorganic WC medium [17] at $21^{\circ} \mathrm{C}$ under $60 \mu \mathrm{mol}$ photons $\cdot \mathrm{m}^{-2} \cdot \mathrm{s}^{-1}$ irradiance of daylight white fluorescent light (Osram, Osasco, SP, Brazil) with 12 hours of photoperiod. Algae were kept in $250 \mathrm{~mL}$ erlenmeyers with $50 \mathrm{~mL}$ of medium and shaken occasionally. In order to obtain larger quantities of biomass, cells were grown in $4000 \mathrm{~mL}$ erlenmeyers with $3500 \mathrm{~mL}$ of medium under continuous aeration $\left(10 \mathrm{~mL} \cdot \mathrm{min}^{-1}\right)$.

Cells were collected at the middle of stationary phase of growth given that at this stage of growth, the maximum batch biomass yield is obtained. Moreover, it is at the stationary phase that algae stop dividing and begin to accumulate photosynthates, among them structural polysaccharides, besides showing less night biomass loss [18].

Cells were centrifuged at $10,400 \times \mathrm{g}$ for $10 \mathrm{~min}$ in a Sorval centrifuge (Sorval Instruments, Wilmington, Del, USA), washed twice with distilled water, resuspended in $50 \mathrm{mM}$ citrate buffer $\mathrm{pH} 4.8$ to form a concentrated suspension and frozen until use. Before the freezing step, an aliquot of $1 \mathrm{~mL}$ of this suspension was used to determine the dry cell mass content whereby $64 \mathrm{mg}$ cell dry weight were recovered from $1 \mathrm{~mL}$ of the concentrated cell suspension. Alternatively, instead of being resuspended in citrate buffer and frozen, cells were washed twice with chilled 95\% ethanol, cold dried and ground with a pestle and mortar until a fine powder was obtained. The dried, cell powder was kept frozen until use.

2.2. Enzymatic Hydrolysis. Cells were hydrolyzed by a mixture of cellulases, xylanases, and amylases enzymes produced by Tricoderma reesei-RUT C30 and Aspergillus awamori $[19,20]$ in a proportion of $10 \mathrm{FPU} / \mathrm{g}$ dry mass and $1 \mathrm{~g}$ cell (dry mass) $/ 10 \mathrm{~mL}$ of the reaction medium. The algae frozen suspensions were thawed, its volume measured, and its dry mass concentration was used to calculate the amount of enzyme preparation necessary to provide an enzyme load of $10 \mathrm{FPU} / \mathrm{g}$ dry mass. The reaction volume was afterwards corrected with $50 \mathrm{mM}$ citrate buffer $\mathrm{pH} 4.8$ to give a final cell (dry mass) concentration of $1 \mathrm{~g} / 10 \mathrm{~mL}$ of the reaction medium which was incubated at $50^{\circ} \mathrm{C}$ in a rotatory shaker (Innova, New Brunswick Scientific, Edison, NJ, USA) using a glass capped erlenmeyer. Aliquots were withdrawn after 0 , $2,4,6$, and $24 \mathrm{~h}$ of hydrolysis, incubated for $5 \mathrm{~min}$ in a boiling water bath to quench the enzymatic reaction, centrifuged to sediment solid particles and the supernatants were used for glucose and reducing sugars determination. The conditions for the hydrolysis experiments, which were carried out using chilled 95\% ethanol, cold dried, and ground cells were the same, however sampling was only carried out after $24 \mathrm{~h}$ of hydrolysis.

2.3. Sugar Determination. YSI 2730 glucose analyzer (Yellow Springs Incorporated, Ohio, USA) was used for glucose concentration measurement. Reductant sugars were determined by the 3,4-dinitrosalicylic acid method (DNS) [21] using a solution of $10 \mathrm{mM}$ glucose as standard.

2.4. Biomass Hydrolysis Yield Calculation. Hydrolysis yields were expressed on a dry biomass base. Data for glucose concentration $\left(\mathrm{g} \cdot \mathrm{L}^{-1}\right)$ and reductant sugars concentration $\left(\mu \mathrm{mol} \cdot \mathrm{mL}^{-1}\right)$ were normalized so that hydrolysis yields were expressed in gram of glucose/reducing sugar per $100 \mathrm{~g}$ of dry biomass.

2.4.1. Calculation for Glucose Yield. The glucose analyser gives the results in $\mathrm{g} \cdot \mathrm{L}^{-1}$. Let $C$ be the glucose concentration in the reaction mixture supernatant and $V(\mathrm{~mL})$ the total volume of the hydrolysis reaction. For the determination of the total glucose amount in grams $(m)$, resulting from a known amount of dry biomass, the concentration $C$ must be divided by 1000 and multiplied by $V$, as shown in

$$
m=\frac{V}{1000} \cdot C
$$

The hydrolysis yield $(Y)$ was expressed in gram of glucose per $100 \mathrm{~g}$ of dry biomass according to (2), where the mass 


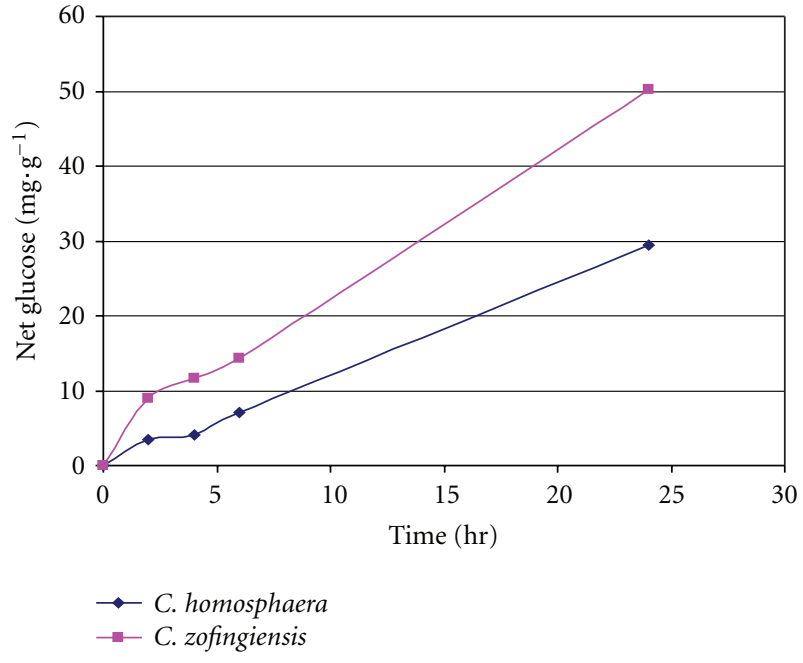

Figure 1: Time course for glucose accumulation upon the enzymatic hydrolysis of C. homosphaera and C. zofingiensis polysaccharides. Cells suspensions (100 mg dry mass $\cdot \mathrm{mL}^{-1}$ ) in $50 \mathrm{mM}$ citrate buffer $\mathrm{pH} 4.8$ were hydrolyzed by a mixture of cellulases, xylanases, and amylases enzymes produced by Tricoderma reeseiRUT C30 and Aspergillus awamori-for $24 \mathrm{~h}$ at $50^{\circ} \mathrm{C}$. Aliquots were withdrawn at $0,2,4,6$, and $24 \mathrm{~h}$ hydrolysis.

in gram of biomass used in the experiments of hydrolyses is represented by $m_{b}$.

$$
\begin{gathered}
Y \equiv \frac{100}{m_{b}} \cdot m=\frac{100}{m_{b}} \cdot \frac{V}{1000} \cdot C \\
\therefore Y=\frac{V \cdot C}{10 \cdot m_{b}} .
\end{gathered}
$$

2.4.2. Calculation for Reducing Sugar Yield (Hexose Equivalents). The results obtained from DNS method gives the results in $\mu \mathrm{mol}$ reducing sugar $\cdot \mathrm{mL}^{-1}$. Let $c$ be the concentration of reducing sugar in the reaction mixture supernatant. In order to express this concentration in $\mathrm{mol} \cdot \mathrm{mL}^{-1}\left(c^{\prime}\right), c$ must be divided by $10^{6}$ or multiplied by $10^{-6}$

$$
c^{\prime}=10^{-6} \cdot c .
$$

Multiplying (3) by the molar mass it is obtained the concentration in gram per milliliter $(\mathrm{cg})$. All hexoses have the same molecular mass; its value is $180 \mathrm{~mol} / \mathrm{g}$. Equation (3) then becomes

$$
\begin{gathered}
c g=180 \cdot c^{\prime} \quad \therefore c g=180 \cdot 10^{-6} c \\
\therefore c g=0.18 \cdot 10^{-3} \cdot c .
\end{gathered}
$$

The total amount of reducing sugar in grams $(m)$ within the reactor is obtained multiplying $c g$ by the volume of the hydrolysis reaction mixture $(V)$ as defined previously. Equation (4) becomes:

$$
m=V \cdot c g \quad \therefore m=0.18 \cdot 10^{-3} \cdot c \cdot V .
$$

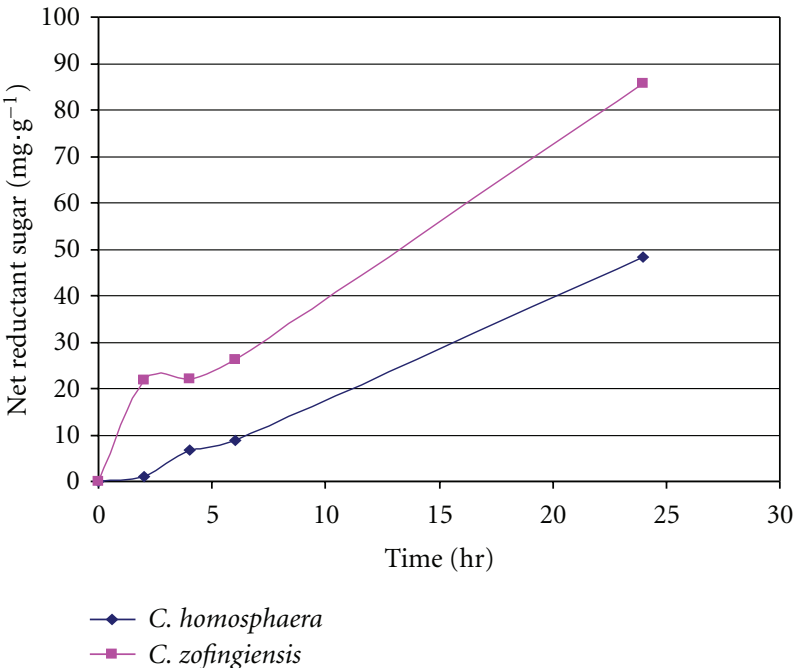

FIGURE 2: Time course for reductant sugars accumulation upon the enzymatic hydrolysis of C. homosphaera and C. zofingiensis polysaccharides. Conditions as described in Figure 1.

The hydrolysis yield $(Y)$ is calculated as shown previously:

$$
\begin{gathered}
Y \equiv \frac{100}{m_{b}} \cdot m=\frac{100}{m_{b}} \cdot 0.18 \cdot 10^{-3} \cdot c \cdot V \\
\therefore Y=0.018 \cdot \frac{c \cdot V}{m_{b}} .
\end{gathered}
$$

If results were to be expressed in milligram of glucose/reducing sugar per gram of dry biomass $\left(Y^{\prime}\right), Y$ had to be multiplied by 1000 and divided by $100:\left(Y^{\prime}=10 \cdot Y\right)$.

\section{Results and Discussion}

Figures 1 and 2 show the time course, up to 24 hours, for glucose and reducing carbohydrates (hexose equivalents) accumulation, in the enzymatic hydrolysis experiments using the biomass of $C$. homosphaera and C. zofingiensis, respectively. Results were expressed as milligram of sugar per gram of dry biomass. A continuous increase in the amount of hydrolyzed glucose and total reducing carbohydrates was observed within the 24 hours of experimental assay. As a sugar concentration plateau was not reached it is likely that higher concentrations would be reached upon a longer incubation period. The amount of hydrolyzed sugars, either glucose or total reducing sugars, were consistently higher for C. zofingiensis. After $24 \mathrm{~h}$ hydrolysis, C. homosphaera yielded a $2.9 \%$ of hydrolyzed glucose and $4.8 \%$ of total reducing sugars whereas C. zofingiensis yielded 5.0 and $8.6 \%$, respectively, on a dry biomass base, indicating this material to be more prone to enzymatic hydrolysis. When the amount of glucose relative to total reducing sugar, was calculated, it was found that $60.4 \%$ of all reducing sugars was glucose for C. homosphaera and $58.1 \%$ for C. zofingiensis. It is also interesting to note that, although the amount of hydrolysed sugars was higher for C. zofingiensis the proportion of 


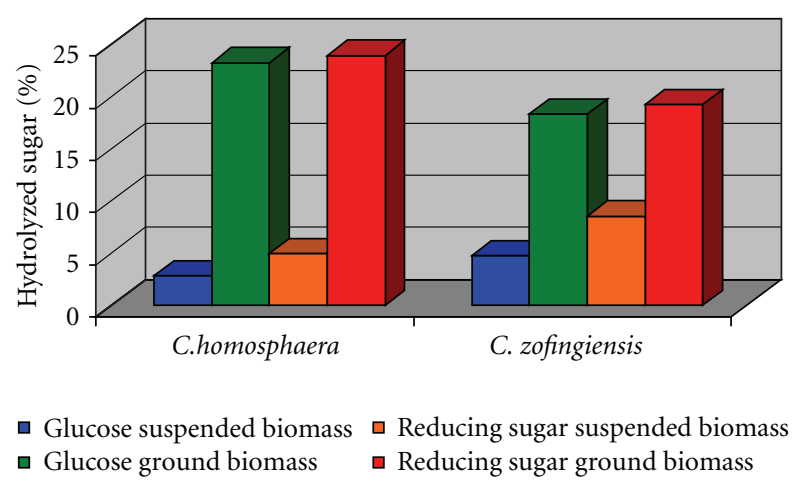

Figure 3: Effect of biomass pretreatment on hydrolyzed sugar yields for C. homosphaera and C. zofingiensis. Cells pellet were resuspended in citrate buffer $\mathrm{pH} 4.8$ and subjected to enzymatic hydrolysis (blue and orange bars) or washed twice with chilled ethanol 95\% (v/v), cold dried and ground, and then subjected to enzymatic hydrolysis in citrate $\mathrm{pH} 4.8$ buffer (green and red bars). Hydrolyzed glucose (blue and green bars) and total reductant sugars (orange and red bars) were determined.

glucose to reducing sugars was the same, suggesting that both species may have similar cell wall composition and structure, allowing a similar enzymatic attack. These results are consistent to the cell wall structure and composition previously reported [14], since their cell walls show similar sugar composition and their polysaccharides are composed predominantly by glucose and mannose.

The set of enzymatic hydrolysis experiments using cells which were washed with chilled 95\% (v/v) ethanol, cold dried and ground showed a dramatic increase in the hydrolysis yield after $24 \mathrm{~h}$ as shown in Figure 3. C. homosphaera yielded $23.3 \%$ of hydrolyzed glucose and $24.5 \%$ of reductant carbohydrates, whereas C. zofingiensis yielded 18.4 and $19.3 \%$, respectively, on a dry biomass base. These data indicated an 8 fold increase in the amount of hydrolyzed glucose and 4.8-fold in that of reductant sugars for $C$. homosphaera whereas for C. zofingiensis the increase, nevertheless lower, of 3.8- and 2.2-folds, respectively, was also important. Interestingly, the algae biomass pretreatment procedure leveled the yield of hydrolyzed sugars for both species (Figure 3 ). It could be argued that these results might not be comparable with those obtained from the suspended biomass (Figure 2) because the hydrolysis time course was not done for the pretreated biomass. That would indeed be true if the subject of comparison were the time course for enzymatic progression. However the purpose of this procedure was solely to compare the hydrolysis sugar yield, for both materials, within $24 \mathrm{~h}$ reaction.

Besides the significant improvement in the algae biomass hydrolysis yield, it was found that glucose represented $95.1 \%$ of the total hydrolyzed sugars for C. homosphaera and $95.3 \%$ for $C$. zofingiensis which is quite remarkable considering the diversified sugars composition of the algae cell wall. This might suggest that the dehydration and powdering pretreatment procedures have destabilized the algae cell wall, specially the outer cell wall, allowing the selective action of the enzymes blend in the cellulose ultrastructures of the cell wall that were not available in the native cell wall structure.

Although the algae biomass starch content was not determined, it is not possible to rule out starch hydrolysis into glucose due to the high amylases content of the enzyme blend which was used in this study [19].

In a similar study, Fu et al. [22] investigated the hydrolysis of cell wall of Chlorella sp. using immobilized cellulase. The authors reported a yield of 58\% of hydrolyzed glucose relative to total sugar content after $24 \mathrm{~h}$ of continuous enzyme treatment. Considering that cellulose represents 33\% of the algal dry biomass in C. pyrenoidosa [2], and assuming that this is true for all species of the genus Chlorella, the aforementioned hydrolysis yield corresponds to a $19.4 \%$ yield on a dry biomass base. These results are similar to those found in this study.

It is also important to emphasize the concentration of glucose syrup, of $23.3 \mathrm{~g} \cdot \mathrm{L}^{-1}$ for C. homosphaera and $18.4 \mathrm{~g} \cdot \mathrm{L}^{-1}$ for $C$. zofingiensis showing that higher concentrations may be achieved upon the optimization of these initial working conditions. As such, Chlorella sugar syrups are promising as renewable resources for a bioethanol or biorefinery platform.

The continuation of this study will include analysis of the algae biomass starch content, optimization of the pretreatment conditions for both the dehydration and the grinding steps, and improvement of the enzymatic hydrolysis conditions, considering temperature, $\mathrm{pH}$, and incubation time, as well as the enzyme load, aiming to increase yields and to decrease the hydrolysis time. Studies will also determine and compare with the literature the cell wall composition of both species, analyze the hydrolysates reducing sugars composition and the carbohydrate composition of the residual nonhydrolyzed algae polysaccharides, as well as the adequacy of the algae sugar syrups for ethanol fermentation by Saccharomyces cerevisiae.

\section{Conclusions}

The use of C. homosphaera and C. zofingiensis as a source of biomass for second generation ethanol production showed to be quite promising. High yields of the fermentable sugar glucose were obtained from the algae biomass, by the use of a simple pre-treatment procedure, which involved dehydration and grinding, followed by hydrolysis by an enzyme blend, produced by Tricoderma reesei-RUT C30 and Aspergillus awamori. This enzyme poll presented a collection of activities which proved to be adequate for the cell wall degradation of the algae species which were evaluated in this study.

\section{Acknowledgments}

The authors are thankful to the graduate students of the Biochemistry Program of the Chemistry Institute of UFRJ, Ayla Sant'Ana da Silva and Raul Alves de Oliveira for providing the Trichoderma reesei-RUT C30 and Aspergillus awamori-enzyme blend which was used in this work. The authors acknowledge the financial support from FINEP and CNPq. 


\section{References}

[1] R. P. John, G. S. Anisha, K. M. Nampoothiri, and A. Pandey, "Micro and macroalgal biomass: a renewable source for bioethanol," Bioresource Technology, vol. 102, no. 1, pp. 186193, 2011.

[2] D. H. Northcote, K. J. Goulding, and R. W. Horne, "The chemical composition and structure of the cell wall of Chlorella pyrenoidosa," The Biochemical Journal, vol. 70, no. 3, pp. 391-397, 1958.

[3] T. Yamada and K. Sakaguchi, "Comparative studies on Chlorella cell walls: induction of protoplast formation," Archives of Microbiology, vol. 132, no. 1, pp. 10-13, 1982.

[4] P. Blokker, S. Schouten, H. Van den Ende, J. W. De Leeuw, P. G. Hatcher, and J. S. Sinninghe Damsté, "Chemical structure of algaenans from the fresh water algae Tetraedron minimum, Scenedesmus communis and Pediastrum boryanum," Organic Geochemistry, vol. 29, no. 5-7, pp. 1453-1468, 1998.

[5] J. Burczyk, B. Śmietana, K. Termińska-Pabis, M. Zych, and P. Kowalowski, "Comparison of nitrogen content amino acid composition and glucosamine content of cell walls of various chlorococcalean algae," Phytochemistry, vol. 51, no. 4, pp. 491497, 1999.

[6] B. Allard and J. Templier, "Comparison of neutral lipid profile of various trilaminar outer cell wall (TLS)-containing microalgae with emphasis on algaenan occurrence," Phytochemistry, vol. 54, no. 4, pp. 369-380, 2000.

[7] A. W. Atkinson, B. E. S. Gunning, and P. C. L. John, "Sporopollenin in the cell wall of Chlorella and other algae: ultrastructure, chemistry, and incorporation of ${ }^{14} \mathrm{C}$-acetate, studied in synchronous cultures," Planta, vol. 107, no. 1, pp. $1-32,1972$.

[8] L. Krienitz, C. Bock, P. K. Dadheech, and T. Pröschold, "Taxonomic reassessment of the genus Mychonastes (Chlorophyceae, Chlorophyta) including the description of eight new species," Phycologia, vol. 50, no. 1, pp. 89-106, 2011.

[9] E. Braun and H. G. Aach, "Enzymatic degradation of the cell wall of Chlorella," Planta, vol. 126, no. 2, pp. 181-185, 1975.

[10] E. Loos and D. Meindl, "Cell wall-lytic activity in Chlorella fusca," Planta, vol. 160, no. 4, pp. 357-362, 1984.

[11] H. Takeda and T. Hirokawa, "Studies on the cell wall of Chlorella I. Quantitative changes in cell wall polysaccharides during the cell cycle of Chlorella ellipsoidea," Plant and Cell Physiology, vol. 19, no. 4, pp. 591-598, 1978.

[12] E. Loos and D. Meindl, "Composition of the cell wall of Chlorella fusca," Planta, vol. 156, no. 3, pp. 270-273, 1982.

[13] H. Takeda, "Classification of Chlorella strains by cell wall sugar composition," Phytochemistry, vol. 27, no. 12, pp. 3823-3826, 1988.

[14] H. Takeda, "Sugar composition of the cell wall and taxonomy of Chlorella (Chlorophyceae)," Journal of Phycology, vol. 27, pp. 224-232, 1991.

[15] H. Takeda, "Taxonomical assignment of chlorococal algae from their cell wall composition," Phytochemistry, vol. 34, no. 4, pp. 1053-1055, 1993.

[16] P. W. Behrens, S. E. Bingham, S. D. Hoeksema, D. L. Cohoon, and J. C. Cox, "Studies on the incorporation of $\mathrm{CO}_{2}$ into starch by Chlorella vulgaris," Journal of Applied Phycology, vol. 1, no. 2, pp. 123-130, 1989.

[17] R. R. Guillard and C. J. Lorenzen, "Yellow-green algae with chlorophyllide," Journal of Phycology, vol. 8, no. 1, pp. 10-14, 1972.

[18] J. C. Ogbonna and H. Tanaka, "Night biomass loss and changes in biochemical composition of cells during light/dark cyclic culture of Chlorella pyrenoidosa," Journal of Fermentation and Bioengineering, vol. 82, no. 6, pp. 558-564, 1996.

[19] E. Bon and C. Webb, "Glucoamylase production and nitrogen nutrition in Aspergillus awamori," Applied Biochemistry and Biotechnology, vol. 39-40, no. 1, pp. 349-369, 1993.

[20] L. M. F. Gottschalk, R. A. Oliveira, and E. P. D. S. Bon, "Cellulases, xylanases, $\beta$-glucosidase and ferulic acid esterase produced by Trichoderma and Aspergillus act synergistically in the hydrolysis of sugarcane bagasse," Biochemical Engineering Journal, vol. 51, no. 1-2, pp. 72-78, 2010.

[21] J. B. Sumner, "Dinitrosalicylic acid: a reagent for the estimation of sugar in normal and diabetic urine," Journal of Biological Chemistry, vol. 62, p. 285, 1924.

[22] C. C. Fu, T. C. Hung, J. Y. Chen, C. H. Su, and W. T. Wu, "Hydrolysis of microalgae cell walls for production of reducing sugar and lipid extraction," Bioresource Technology, vol. 101, no. 22, pp. 8750-8754, 2010. 

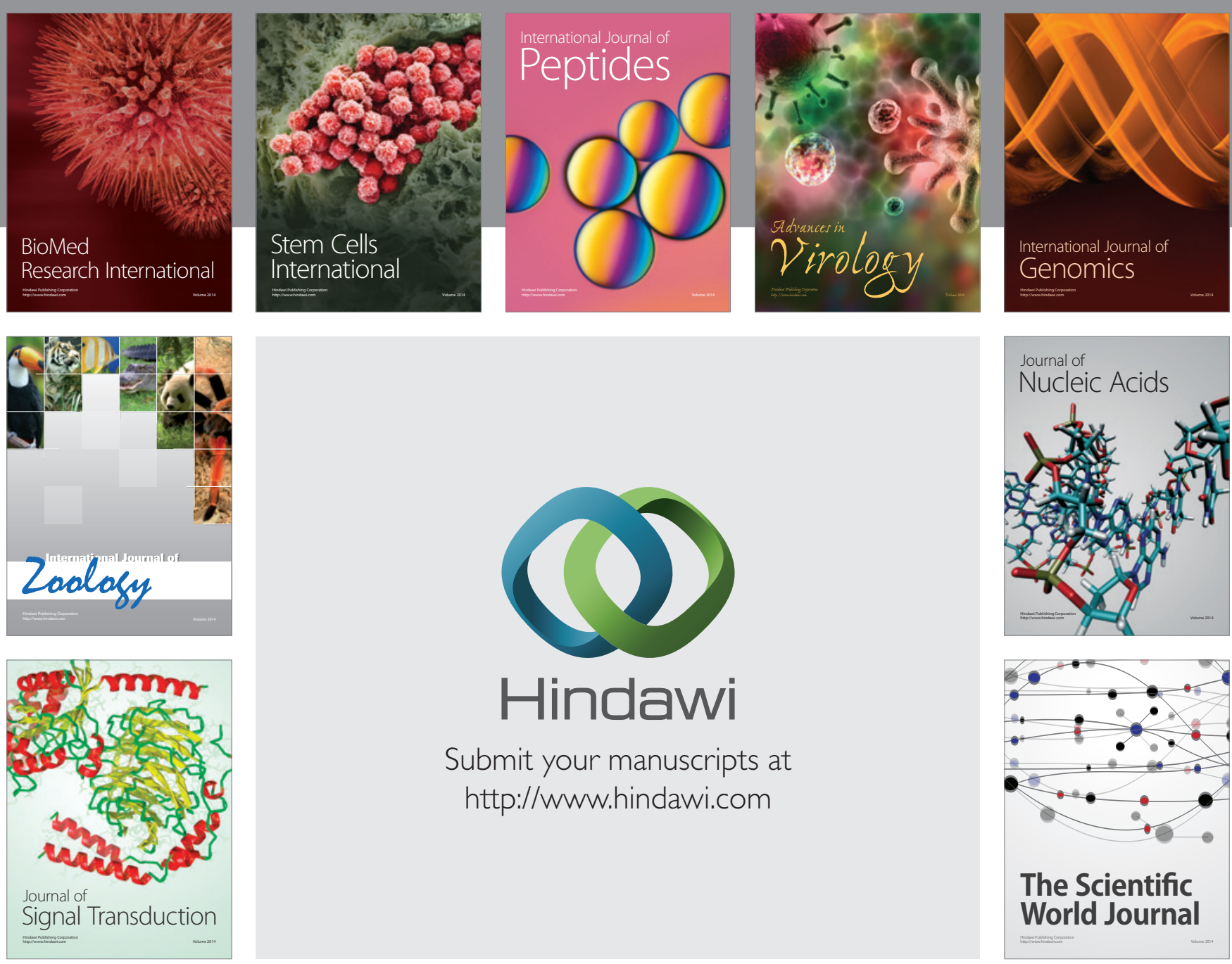

Submit your manuscripts at

http://www.hindawi.com
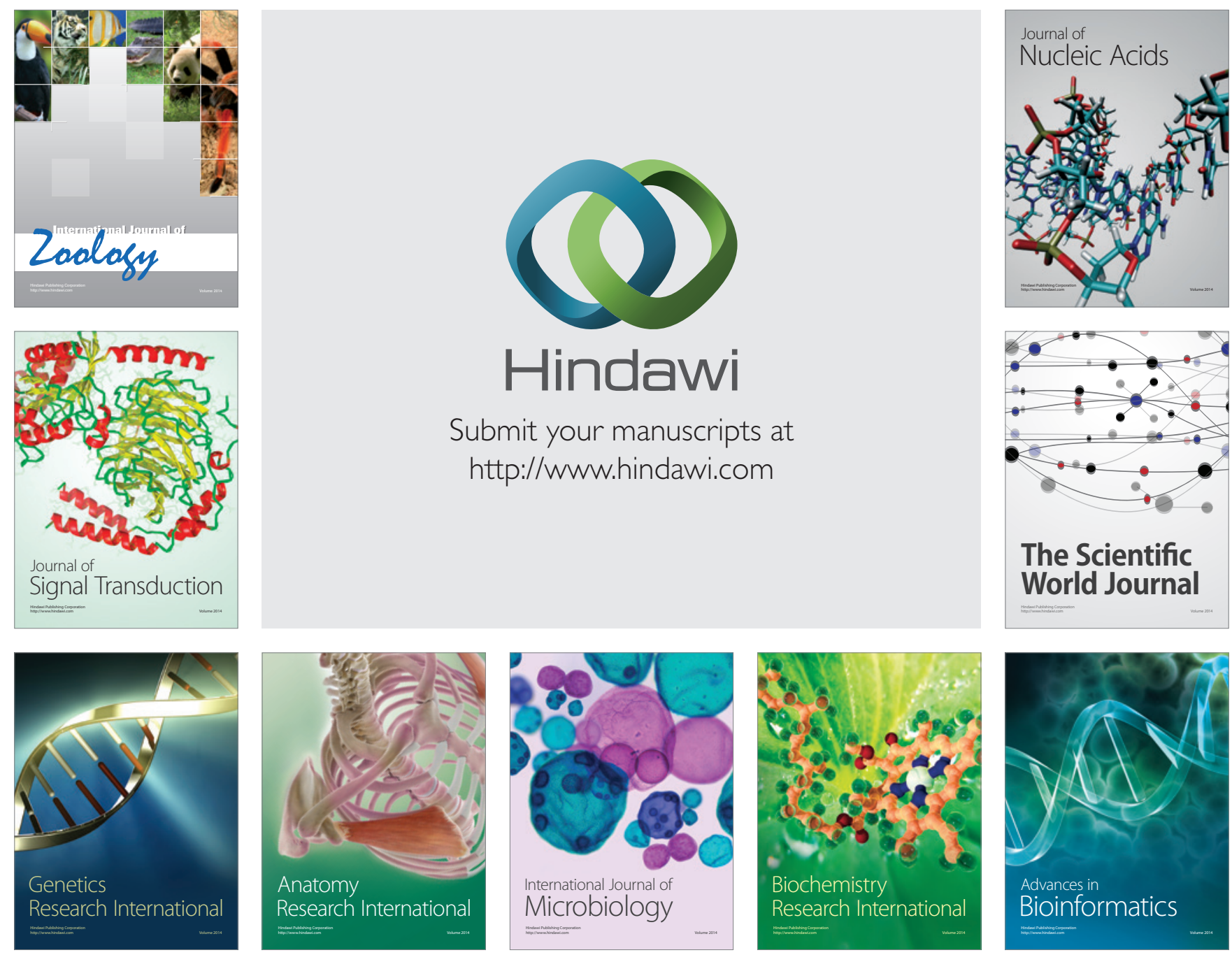

The Scientific World Journal
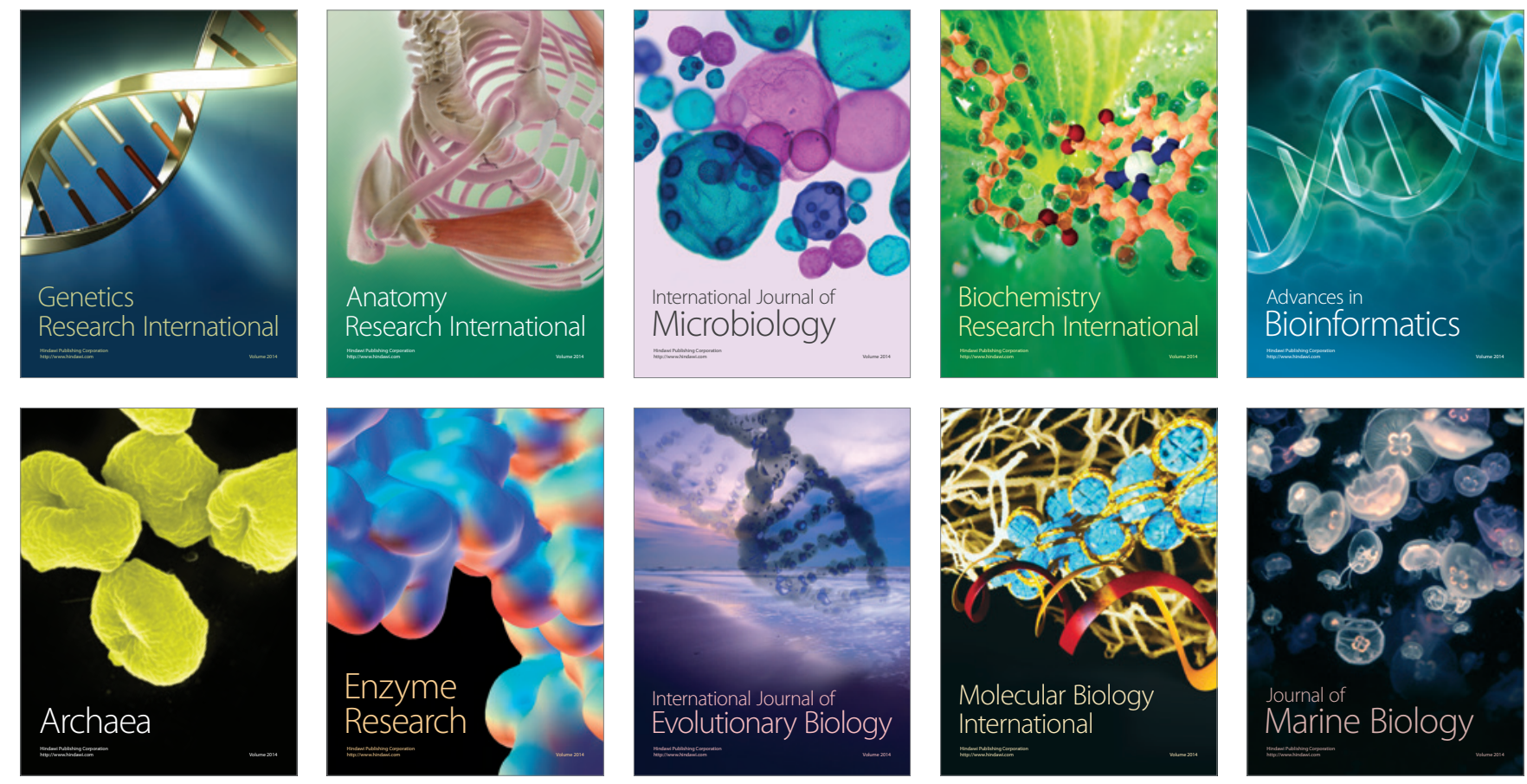